\title{
THE IMPACT OF REGIONAL TRADE AGREEMENTS TO THE COMMODITY TRADE FLOWS (CASE STUDY: INTERNATIONAL PALM OIL TRADE)
}

\author{
Riska Pujiati ${ }^{1)}$, Muhammad Firdaus ${ }^{2}$, Andriyono Kilat Adhi ${ }^{3)}$ \\ and Bernhard Brümmer ${ }^{4)}$ \\ ${ }^{1,2,3)}$ Magister Sains Agribisnis, Fakultas Ekonomi dan Manajemen, Institut Pertanian Bogor \\ ${ }^{4)}$ Department of Agricultural Economics and Rural Development, \\ Georg August University of Goettingen, Germany \\ ${ }^{1)}$ r.pujiati@gmail.com
}

\begin{abstract}
Indonesia and Malaysia are the major exporters of palm oil in South East Asia. South East Asia Regional Trade Agreement can affect worldwide trade flow of palm oil. The objective of this study is to examine the effect of the Regional Trade Agreement on the trade flows of Indonesian and Malaysian palm oil. The effect is analyzed with gravity model. The result shows positive dynamic effect of Free Trade Agreement to palm oil trade flow. Regional Trade Agreement has higher impact to Malaysia than Indonesia due to dissimilar government policies.
\end{abstract}

Keyword(s): gravity model, palm oil, regional trade agreement.

\begin{abstract}
ABSTRAK
Indonesia dan Malaysia adalah eksportir utama minyak kelapa sawit di Asia Tenggara. Perjanjian Perdangangan Regional Asia Tenggara dapat mempengaruhi aliran perdagangan dunia komoditas minyak kelapa sawit. Penelitian ini bertujuan untuk memeriksa dampak Perjanjian Perdangangan Regional tersebut terhadap aliran perdagangan minyak kelapa sawit dari Indonesia dan Malaysia. Dampak tersebut dianalisa dengan model gravity. Hasil penelitian menunjukkan dampak positif dinamik Regional Perjanjian Perdangangan Regional terhadap aliran perdagangan komoditi minyak kelapa sawit dari Indonesia dan Malaysia. Dampak terhadap Malaysia lebih besar dibandingkan Indonesia karena perbedaan kebijakan pemerintah.
\end{abstract}

Kata Kunci: model gravity, minyak kelapa sawit, perjanjian perdagangan regional.

\section{INTRODUCTION}

International agricultural trade is important, especially in developing countries. The total share of agricultural exports from developing countries increased slightly over the two decades between 1990 and 2010, from 37 to 43 percent (Cheong et al., 2013). Agriculture plays an important role for developing countries as a primary source of income (Aksoy \& Beghin, 2004).

In many developing countries, agriculture also becomes a strategic sector which absorbs a high number of employment opportunities. Southeast Asia is a region that consists of middle income developing economies, with two countries contributing as the region's major exporters, Indonesia and Malaysia. 


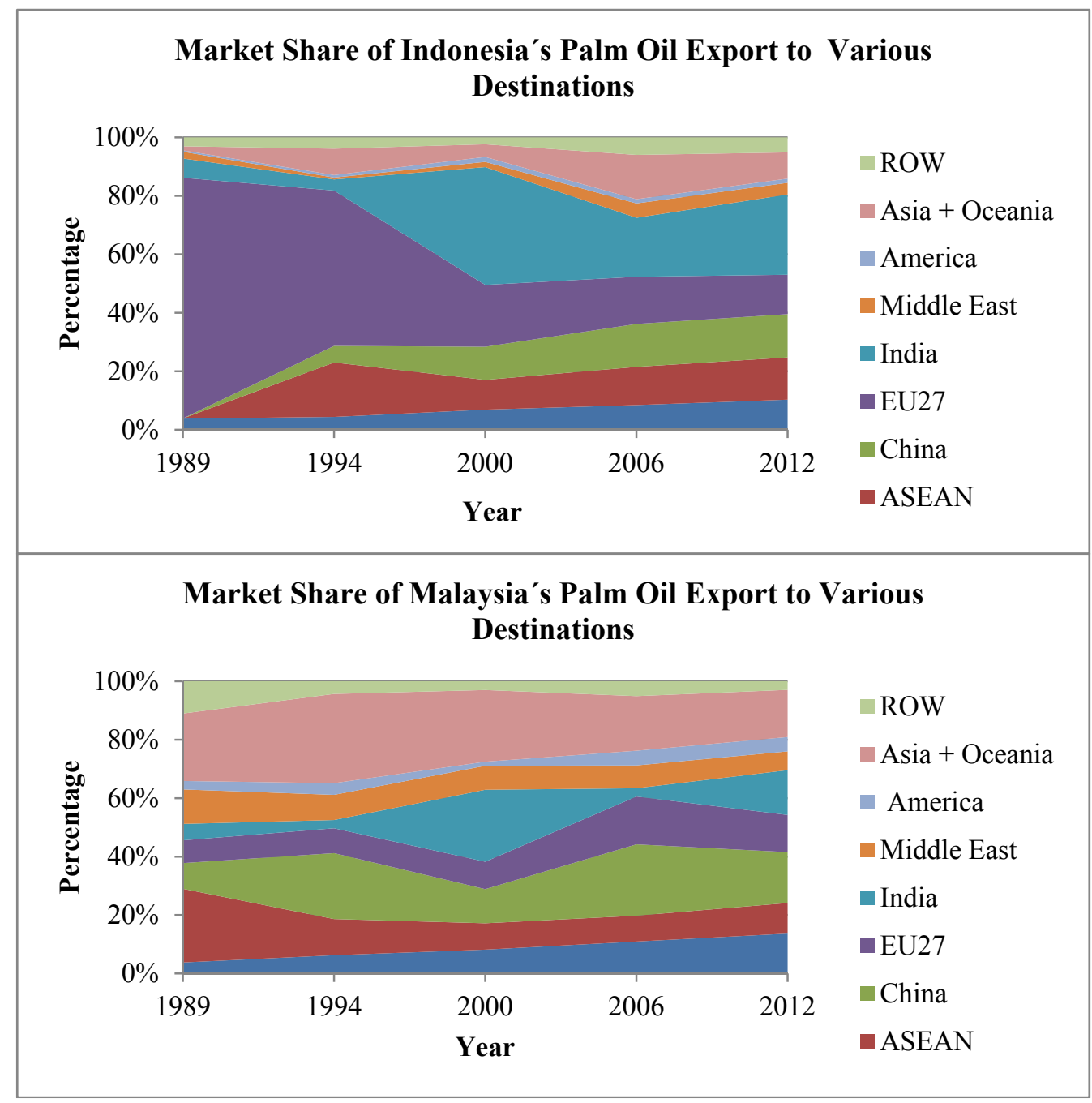

Source: UN Comtrade, acessed through WITS, 2013

Figure 1. Market Shares of Indonesia and Malaysia's Palm Oil Export

In 2012, the value of the total agriculture exports reached US\$ 45 billion for Indonesia and US\$ 34 billion for Malaysia (WTO, 2012).

The major commodity which contributes to the high value of export is vegetable oil initially originated from palm oil. Palm oil is exported in two primary forms: crude and refined.
Furthermore, there are more than 100 countries listed as the destination of Indonesian and Malaysian palm oil. Figure 1 shows the palm oil market share for both countries.

According to the Figure 1, Indonesia and Malaysia have different shares of the palm oil market between the periods of 1989-2012. The European Union (EU) 
was the primary trading partner of Indonesia with the total market share reach by 82 percent in 1989, this share dropped significantly to 14 percent in 2012. For Malaysia, the share for the EU increased slightly from 8 percent in 1989 to 13 percent in 2012. China is considered to be the new emerging nations, both in economy and population, and is therefore showing a tremendous increase in the import of the palm oil. For palm oil originating from Indonesia, the export share to China reached 15 percent in 2012 compared to three percent in 1989, while for Malaysia, the export share to China reached 17 percent in 2012 compared to 9 percent in 1989.

Another country which shows dramatic import increases of palm oil is India. In 2012, Indonesia's palm oil export share reached 28 percent while in 1989 the share was only 7 percent. Similar cases apply to Malaysia, where the export share to India reached 15 percent in 2012, three times larger than in 1989 at only 5 percent. Similar to China and India, the export share of Indonesia's palm oil to countries grouped to the Association of Southeast Asian Nations (ASEAN) has increased to 14 percent in 2012. Contrary to Malaysia, the export share of Malaysia's palm oil to ASEAN market decreased from 25 percent in 1989 to 11 percent in 2012 .

The change of the palm oil export proportion is influenced in part by the establishment of trade agreements among countries. Indonesia and Malaysia are involved in similar free trade agreements, which are part of the ASEAN Free Trade Area (AFTA) Agreement. During the period between 2000 and 2012, there has been an expansion of partnership with ASEAN; newly added countries are: China (2005), Korea (2007), Japan (2008), India (2010) and Australia/New Zealand (2010).

As two of the largest producers, joining the AFTA become an opportunity for Indonesia and Malaysia to promote trade because of the reduction in trade barriers. Although Indonesia and Malaysia produce similar products, involvement in the RTA will give different results in the flow of goods. Based on the description above, the objective of this research is to analyze the impact of the establishment of regional trade agreements on Indonesia and Malaysia's palm oil trade flows.

\section{LITERATURA REVIEW}

Viner introduced the terms trade creation and trade diversion in 1950; trade creation refers to a shift of product origin from expensive domestic producers to more efficient producers which are a member of trade agreement. Trade diversion occurs when a member country transfers its imported goods from a country that is outside of the trade agreement to a member country within the trade region. Specific on agricultural commodities, the impact of FTA establishment was analyzed by Lambert and McKoy on 2009. Their results from the gravity model estimation indicates that FTA generally increases trade in agriculture and trade sector. Philippidis et al. (2013) examine the bilateral trade flow on 20 single agricultural commodities between period 2001 to 2004 within 95 country, 
their research result shows that the FTAs has significant impact to trade on wheat and other cereal gains; and paddy rice.

The gravity model was introduced by Tinbergen (1962). According to this model, trade between countries is explained by economic sizes, populations, direct geographical distances and a set of dummy variables. The initial gravity model can expressed as :

$$
X_{i j}=\beta_{0}\left(Y_{i}\right)^{\beta_{1}}\left(Y_{j}\right)^{\beta}\left(D_{i j}\right)^{\beta_{3}} \mu_{i j}
$$

where $X_{i j}$ is the value of bilateral trade (export or import) in current US dollars, $Y_{i}$ and $Y_{j}$ represent exporter and importer's economic size, $D_{i j}$ is the distance between the two country, $\mu_{i j}$ is the disturbance term, and the $\beta$ s are the unknown parameters of the equation. The microeconomic foundation of gravity equation was established by Anderson in 1979.

In Anderson's theory the goods are differentiated by their origin. However, Anderson's model was not really recognized by trade economists (Head \& Mayer, 2013). The next theoretical foundation of the gravity equation set by Bergstrand (1985, 1989) who developed a connection between endowment factors and the bilateral trade model. Bergstrand (1989) shows that the gravity model is a practical example of the monopolistic competition theory as developed by Krugman in 1980.

The renowned work of Anderson and Van Wincoop (2003) "gravity with gravitas" has successfully laid the theoretical foundation of the gravity equation and has been completed by many other researchers. Principally, the Anderson and Van Wincoop (AVW) gravity model originated from a demand function. The structure of the model was based on the final formula of the constant elasticity of substitution equation for consumer preferences. Consumers have "love of variety", by consuming a greater variety of goods, the overall utility increases. The second assumption of the AVW gravity model follows Krugman's (1980) production function; under the condition of increasing returns to scale, each firm produces one particular product. The large number of firms diminish the competition, the price is constant and can cover firm the firm's marginal costs and fixed costs. In international trade, trade cost's regularly occurand become somewhat of a barrier.

The AVW model shows the importance of controlling relative trade costs. Their results indicate that bilateral trade is influenced by relative trade cost. Country $\mathrm{j}$ imports from country $\mathrm{i}$ and must pay a price which is influenced by the weighted average trade cost being paid to all other trading partners. The derivation of the AVW model can be seen in the appendix. The cross sectional gravity equation by AVW is summarized below :

$$
X_{i j}=\frac{Y_{i} Y_{j}}{Y}\left(\frac{\tau_{i j}}{\Pi_{i} P_{j}}\right)^{1-\sigma}
$$

Taking the logarithm on both sides:

$$
\begin{aligned}
& \ln X_{i j}=\ln Y_{i}+\ln Y_{j}-\ln Y \\
& +(1-\sigma) \ln \left(\frac{\tau_{i j}}{\Pi_{i} P_{j}}\right)
\end{aligned}
$$


where $X_{i j}$ is the trade value from country i to $\mathrm{j}$, and $Y$ represents the world GDP. $Y_{i}$ is the GDP of country $i, Y_{j}$ is the GDP of country $\mathrm{j}, \sigma_{k}$ denotes the elasticity of substitution and $\tau_{i j}^{k}$ represents trade costs. Two important features of the AVW model is the two additional variables, $\Pi_{i}^{k}$ and $P_{i}^{k} \cdot \Pi_{i}^{k}$ is called the outward multilateral resistance, and $P_{i}^{k}$ is called the inward multilateral resistance. The outward multilateral resistance denotes the exports from country $i$ to country $j$ depending on trade costs across all possible export markets. The inward multilateral resistance denotes the imports into country $i$ from country $j$ depending on trade costs across all possible suppliers (Shepherd, 2013). Generally, these figures are low if a country is isolated from world market (Bacchetta, 2012). Inward multilateral resistance is also called the price indexand outward multilateral resistance is called competition (Fally, 2012).

Extensive research has been conducted to examine the determining factor of palm oil trade in the international market. Suryana (1986), Tondok (1998), Ibrahim (1999), and Basiron (2001) analyzed the outlook of palm oil in the international market for Indonesia and Malaysia. Shamsuddin et al. (1997) examined the determinant and implication of policy instruments on the Indonesian and Malaysian palm oil. Lubis (1994), Shamsuddin et al. (1994), and Susila (1995) who examined Malaysia's palm oil supply and demand system.
The impact of the Free Trade Agreements (FTA) proliferation to a country's overall trade especially palm oil was describe by Ernawati et al.(2006). The simulation shows that a reduction of tariff in export and import has varying impacts on partner country. The palm oil demand is influenced by price, as is the price of substituted commodities such as rapeseed oil and soybean oil; exchange rate and lag export, are also shown to be influenced in the simulation. Rifin (2010), performed a study comparing the market share of Indonesian and Malaysian palm oil in Asia, Europe, and throughout Africa. The commodities were differentiated into crude and refined palm oil. The market share was analyzed by constant market share analysis (CMSA). Furthermore, another study concerning the impact of FTAs was conducted by (Balu \& Ismail, 2011). According to their descriptive research, for Malaysia's palm oil industry, the FTAs was a good opportunity because it helped to increase market share and tariff reduction lead to a higher profit. The competitiveness of traded goods will likely enhance due to liberalization of tariffs.

\section{RESEARCH METHOD}

\section{Data Types and Sources}

This study uses secondary data available from various sources. The bilateral trade of palm oil annual data from the period between 1991 and 2011 has been generated from the United Nations Commodity Trade Statistic Database (UN COMTRADE) and further incorporated with the World Integrated Trade Solution (WITS) software. The 
data consists of a nominal value of bilateral trade from Indonesia and Malaysia to 77 partner countries that have conducte trade more than ten times within the 21 year period.

The total palm oil and its fraction which has Harmonized System (HS) code: 1511, divided into crude palm oil (HS code: 151110) and refined palm oil but no chemically modified (HS code: 151190). The geographical distance between countries was obtained from the Centre d'Etudes Prospectives et d'Informations Internationales (CEPII), the importer's GDP and the exchange rate of Purchasing Power Parity (PPP) data came from the World Bank, along with FTA information from the Asia Regional Integration Centre (ARIC). The value of palm oil production is generated from the FAO.

\section{The Gravity Analysis (PPML Estimation)}

The gravity model estimation is utilized to analyze whether the regional trade agreement influences trade flow or not. This study use Poisson Pseudo Maximum Likelihood (PPML) in order to handle zero trade data and heteroskedasticity. PPML method was introduced by Gourieroux et al. (1984) and is commonly used for the count data model. The most influential research concerning the use of PPML as a tool for estimating the gravity model was conducted by Santos Silva and Tenreyro (2006). They argued that the log linear transformation result in an inconsistent bias in the presence of heteroskedasticity, the result from the PPML estimation will provide better result by including the zero value rather than truncating OLS.The subsequent research by Santos Silva and Tenreyro (2011) shows that the PPML is consistent and performs well in the presence of over dispersion (the conditional variance is not equal to the conditional mean) and excess zero values.

Sun and Reed (2010) was the first author who applied PPML on the effect of FTAs with disaggregated data for agriculture commodities. The result of PPML is superior to the OLS result. Following Sun and Reed (2010), the empirical model is specified as:

$$
\begin{aligned}
& Y_{i j t}=\exp \left\{\beta_{0}+\beta_{1} \ln G D P_{i t}+\right. \\
& \beta_{2} \ln G D P_{j t}+\beta_{3} \ln D_{i j}+\beta_{4} F T A_{i j}+\pi_{i j}+\delta_{i}+ \\
& \left.\varphi_{j}+\gamma_{t}+\varepsilon_{i j t}\right\}
\end{aligned}
$$

where $Y_{i j t}$ denotes the export value from country $\mathrm{i}$ to $\mathrm{j}$ at time $\mathrm{t}, \delta_{i}$ stands for the fixed effect of country i (exporter fixed effect), $\varphi_{j}$ represent the fixed effect of country $\mathrm{j}$ (importer fixed effect), $\pi_{i j}$ denotes the country pair fixed effect, and $\gamma_{t}$ refers to the time effect.

\section{Econometric Modelling of International Palm Oil Trade}

Estimating the gravity model for a single commodity can lead to biased estimations if the GDP of exporter countries are used as a proxy for the economic size of the exporter $\left(G D P_{i t}\right)$. Therefore, the production value of palm oil is used in this study as a proxy for the exporter's economic size. In order to examine the impact of free trade, the dummy variable (FTAs) is divided into two parts one before and one for after the 
year 2000. The main reason for splitting up the dummy variable is the proliferation of FTAs for both Indonesia and Malaysia after year 2000, which increase the member of free trade agreement in southeast Asia region. The gravity model of international palm oil takes the following form:

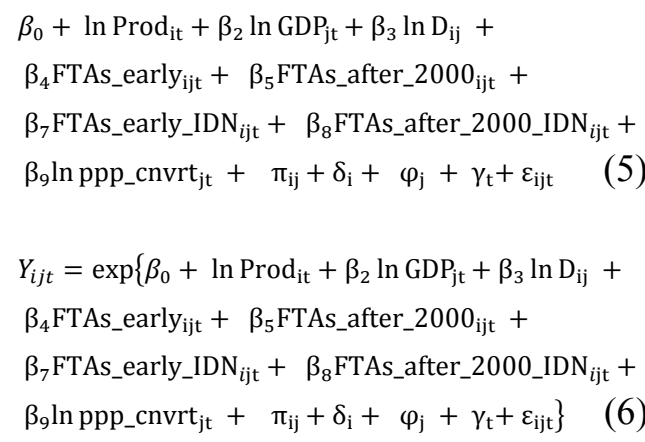

\begin{tabular}{|c|c|}
\hline$Y_{i j t}$ & $\begin{aligned}= & \text { annual palm oil export from } \mathrm{i} \\
& \text { to } \mathrm{j} \text { at year } \mathrm{t} \text { in US\$ }\end{aligned}$ \\
\hline Prod $_{i t}$ & $\begin{aligned}= & \text { annual palm oil production } \\
& \text { value of } \mathrm{i} \text { at year } \mathrm{t} \text { in US\$ }\end{aligned}$ \\
\hline $\mathrm{GDP}_{\mathrm{jt}}$ & $\begin{aligned}= & \text { annual GDP of importer } \\
& \text { country (j) at year } t \text { in US } \$\end{aligned}$ \\
\hline$D_{i j}$ & $\begin{aligned}= & \text { bilateral distance between } \\
& \text { countries in } \mathrm{km}\end{aligned}$ \\
\hline FTA_early ${ }_{\mathrm{ijt}}$ & $\begin{aligned}= & \text { Dummy variable for FTAs } \\
& \text { before year 2000, } 1 \text { if } \\
& \text { exporters and importers have } \\
& \text { signed agreement at time t, } \\
& \text { otherwise } 0\end{aligned}$ \\
\hline FTA_after_2000 & $\begin{array}{l}=\text { Dummy variable for FTAs } \\
\text { after year } 2000,1 \text { if exporters } \\
\text { and importers have signed } \\
\text { agreement at time t, } \\
\text { otherwise } 0\end{array}$ \\
\hline FTA_early_IDN $N_{i j t}$ & $\begin{array}{l}=\text { Dummy variable for FTAs } \\
\text { before year 2000, } 1 \text { if } \\
\text { Indonesia as an exporter and } \\
\text { have signed agreement with } \\
\text { importer country (j) at time t, } \\
\text { otherwise } 0\end{array}$ \\
\hline FTA_after_2000_IDN $\mathrm{ijt}=$ & $\begin{array}{l}=\text { Dummy variable for FTAs } \\
\text { after year 2000, } 1 \text { if } \\
\text { Indonesia as an exporter and } \\
\text { have signed an agreement } \\
\text { with importer country (j) at } \\
\text { time t, otherwise } 0 .\end{array}$ \\
\hline
\end{tabular}

With the above setting thus we expect positive sign for the coefficient of importer's GDP and the coefficient of palm oil production. This means that the export of palm oil will increase as long as there is growth in economy. The distance variable is expected to have negative sign because it is considered as trade barrier. The further destination country the less export quantity is expected. FTAs dummy variable is expected to have positive sign since the commencement of FTAs is meant to reduce trade barriers.

\section{RESULTS AND DISCUSSIONS}

The PPML estimation result applied for analysis concerning the impact of FTAs on the commodity trade flow. The FTA dummy variable is utilized to quantify the change of trade flow due to the establishment of the FTA. The estimation use two main separate dummy variables, before and after year 2000 . Furthermore, based on the results from table 1, the PPML with the combination of time, country pairs and country specific effect is applied to the next estimation. In particular, for deeper analysis the dependent variable are divided into three: total palm oil and its fraction (HS1511), crude palm oil (HS151110), and refined palm oil but no chemically refined (HS151190). The result of the PPML estimation for different palm oil export type can be seen in Table 2.

For total palm oil, the estimated coefficients for palm oil production have the expected positive signs and are statistically significant at the ten percent level, this means that one percent increase 
Table 1. PPML Estimation Result for HS1511, HS151110, and HS151190

\begin{tabular}{|c|c|c|c|}
\hline VARIABLES & $\begin{array}{c}\text { (1) } \\
\text { HS1511 } \\
\text { (total palm oil and } \\
\text { its fraction) }\end{array}$ & $\begin{array}{c}\text { (2) } \\
\text { HS151110 } \\
\text { (crude palm } \\
\text { oil) }\end{array}$ & $\begin{array}{c}\text { (3) } \\
\text { HS151190 } \\
\text { (refined palm } \\
\text { oil) }\end{array}$ \\
\hline ln_Prod_val & $\begin{array}{l}0,391^{*} \\
(0,206)\end{array}$ & $\begin{array}{l}-0,638^{*} \\
(0,381)\end{array}$ & $\begin{array}{r}0,578 * * * \\
(0,163)\end{array}$ \\
\hline ln_GDP & $\begin{array}{r}0,00272 \\
(0,0109)\end{array}$ & $\begin{array}{r}1,150 \\
(0,787)\end{array}$ & $\begin{array}{l}0,00170 \\
(0,0235)\end{array}$ \\
\hline ln_PPP_cnvrt & $\begin{array}{r}0,588 * * * \\
(0,109)\end{array}$ & $\begin{array}{r}-0,588 \\
(0,810)\end{array}$ & $\begin{array}{r}0,713 * * * \\
(0,233)\end{array}$ \\
\hline ln_dist & $\begin{array}{r}-13,08 * * * \\
(1,700)\end{array}$ & $\begin{array}{r}0,758 \\
(0,518)\end{array}$ & $\begin{array}{r}10,44 * * * \\
(0,905)\end{array}$ \\
\hline fta_early & $\begin{array}{r}-1,616^{* * *} \\
(0,234)\end{array}$ & $\begin{array}{r}-1,991 * * * \\
(0,706)\end{array}$ & $\begin{array}{r}-1,493 * * * \\
(0,314)\end{array}$ \\
\hline fta_after_2000 & $\begin{array}{r}-0,225 * * \\
(0,0891)\end{array}$ & $\begin{array}{c}0,481 * \\
(0,279)\end{array}$ & $\begin{array}{r}-0,143 \\
(0,169)\end{array}$ \\
\hline fta_early_IDN & $\begin{array}{r}2,312 * * * \\
(0,299)\end{array}$ & $\begin{array}{r}1,993 * * * \\
(0,490)\end{array}$ & $\begin{array}{r}3,796 * * * \\
(0,363)\end{array}$ \\
\hline fta_after_2000_IDN & $\begin{array}{r}0,724 * * * \\
(0,135)\end{array}$ & $\begin{array}{r}-0,519 * * * \\
(0,187)\end{array}$ & $\begin{array}{r}0,691 * * \\
(0,349)\end{array}$ \\
\hline Constant & $\begin{array}{r}101,7 * * * \\
(12,53)\end{array}$ & $\begin{array}{r}-6,267 \\
(24,63)\end{array}$ & $\begin{array}{r}-81,23 * * * \\
(8,576) \\
\end{array}$ \\
\hline $\begin{array}{l}\text { Observations } \\
\text { R-squared }\end{array}$ & $\begin{array}{l}3.234 \\
0,921\end{array}$ & $\begin{array}{l}3.234 \\
0,966\end{array}$ & $\begin{array}{l}3.234 \\
0,884\end{array}$ \\
\hline
\end{tabular}

Note : standard errors (SE) in parentheses, ${ }^{*} \mathrm{p}<0,1, * * \mathrm{p}<0,05, * * * \mathrm{p}<0,01$

in palm oil production would be associated with an increasing in the average export of palm oil by approximately 0,39 percent, ceteris paribus (cp).

A positive sign was also determined for refined palm oil (HS 151190), with the average export value increasing by about 0,58 percent when the production value increases by one percent, $c p$. The increasing of palm oil export is supported by the increase in the plantation area of palm oil trees. In contrast, the coefficient for the palm oil production variable has a negative sign and is significant for crude palm oil (HS151110), this means that when the production value increases by one percent, the average crude palm oil export will fall by 0,64 percent $c p$. The reason behind the declining of crude palm oil export is that the majority of palm oil are exported had passed the refining process. The GDP coefficient has a positive influence on the palm oil export, the GDP variable was not influential on the palm oil export and is statistically insignificant for all types of palm oil export.

The results are contrary to the gravity theory that trade is influenced by the economic size of the importer. As expected, the distance variable has a negative sign and is statistically 
Table 2. The Change of Palm Oil Export due to FTA establishment (\%)

\begin{tabular}{|c|c|c|c|c|}
\hline \multirow{2}{*}{ Palm Oil HS } & \multicolumn{2}{|c|}{ Indonesia (\%) } & \multicolumn{2}{|c|}{ Malaysia (\%) } \\
\hline & Before 2000 & After $20002^{2}$ & Before $2000^{3}$ & After $2000^{4}$ \\
\hline HS 1511 & 100,57 & 64,71 & $-80,13$ & $-20,15$ \\
\hline HS 151110 (Crude) & 0,20 & $-3,73$ & $-86,34$ & 61,77 \\
\hline HS 151190 (Refined) & 900,41 & 99,57 & $-77,53$ & $-13,32$ \\
\hline \multicolumn{5}{|c|}{$\begin{array}{l}\text { The effect of FTA before } 2000 \text { for Indonesia is the summation of fta_early coefficient and fta_early_IDN } \\
\text { coefficient, } \\
\text { then calculated by }\left\{\left[\exp ^{(\beta)}-1\right] \times 100\right\} \\
{ }^{2} \text { The effect of FTA after } 2000 \text { for Indonesia is the summation of fta_after_ } 2000 \text { coefficient and fta_after_200( } \\
\text { coefficient, then calculated by }\left\{\left[\exp ^{(\beta)}-1\right] \times 100\right\} \\
{ }^{3} \text { The effect of FTA before } 2000 \text { for Malaysia is similar with fta_early coefficient, then calculated by }\left\{\left[\exp ^{(\beta)}-1\right.\right. \\
{ }^{4} \text { The effect of FTA after } 2000 \text { for Malaysia is similar with fta_after_2000 coefficient, then calculated by } \\
\left\{\left[\exp ^{(\beta)}-1\right] \times 100\right\}\end{array}$} \\
\hline
\end{tabular}

significant at the one percent level for total palm oil (HS1511). This indicates that when the bilateral distance increases by one percent,the average palm oil export will fall by $13,08 \%$.

This result indicates that distance acts as trade barrier. The distance coefficient has positive signs for crude and refined palm oil and is statistically significant at one percent level for refined palm oil. This contrary result indicates that for high value product (refined palm oil), the distance does not influenced trade.

Furthermore, the trade flow experiences different changes for Indonesia and Malaysia due to the establishment of trade agreements. Generally, for FTA before 2000, the coefficients are statistically significant and have a negative sign for all types of palm oil. The estimated FTA after 2000 coefficients have a positive result for crude palm oil, and the sign is statistically significant for total and crude palm oil.

For Indonesia itself, the coefficient of FTA before 2000 is positive and statistically significant for all types of palm oil, while after 2000, the FTA coefficients have a negative impact on crude palm oil export. The summary of the percentage changes of exports can be seen in Table 2.

For FTA before year 2000, the results show different effects for Indonesia and Malaysia. For Malaysia, the average total export of palm oil decreases by 80,13 percent, while for crude and refined palm oil, FTA establishment causes an average export decline of 86,34 percent and 77,53 percent respectively, ceteris paribus (c.p.). In particular, the tremendous effect occurs for Indonesia's total palm oil export, as indicated with the variable FTA before year 2000, the average palm oil export increased by 100,57 percent, 0,20 percent, and 900,41 percent, for HS1511, HS151110, and HS151190 respectively, c.p.

The average export of Indonesian palm oil increased by 64,71 percent after the establishment of the FTA from 2001 to 2011. For crude palm oil, the average export decreased by 3,73 percent while 
for refined palm oil, the average changes of export was 99,57 percent higher than export without FTA, c.p. The use of crude palm oil for domestic consumption may become the reason why the change in export of crude palm oil is different than the change in refined palm oil. In fact, Indonesia also counted as the largest consumer of cooking oil which originated from palm oil. The increase in Indonesia's refined palm oil export after the establishment of AFTA could be influenced by the higher demand of palm oil in the international market. The rapid economic growth of countries in the southeast Asia region have become the primary factor for the increased consumption of palm oil, thus, Indonesia's palm oil exports have shifted their destinations to other FTA member countries.

In contrast, the FTA after year 2000 negatively impacted the total value of Malaysia's palm oil export. The establishment of FTA after year 2000 caused the average export value decrease by 20,15 percent.

The opposite effect applied to HS 151110 (crude palm oil), where the average export of crude palm oil increased by 61,77 percent compared to export without FTA, c.p. The reason for the higher export volumes of crude palm oil is due to the establishment of bilateral trade agreements with China, India and Myanmar.

In fact, the market share of Malaysian palm oil in China's market has reached 61 percent, while the Indonesian

${ }^{1}$ Malaysia acquired Shanghai Jinshan Jinwei Chemical 202 share in China's market only reaches 39 percent. Moreover, the Malaysian company has built a refinery in China by doing a joint venture mechanism with a China's company in the beginning 1995.

Taking this into consideration, along with the FTA establishment, Malaysia has additional opportunities to process refined palm oil into downstream products such as oleochemicals (Nor, 2012) $)^{1}$. This is one of the examples of the dynamic effect that has occurred due to the establishment of RTAs, the investment creation effect. For refined palm oil, the FTA after year 2000 has a negative sign, this means that the average export of Malaysia`s refined palm oil decreased by 13,32 percent after the FTA was established, c.p.

This result is correlated with the increased export of crude palm oil, as mentioned previously.

Furthermore, the Malaysian export oriented policy has pushed the development of refineries in Malaysia itself, the refined palm oil is then exported to fulfill the demand for countries outside of the Asian region. Since the year 1990, Malaysian palm oil has acquired the oleochemical industries in several developed countries such as the Netherlands, Germany, Switzerland and the United States (Nor, 2012).

\section{CONCLUSION AND POLICY IMPLICATION}

In summary, the flow of exports is not only influenced by the trade agreement itself, but also by the 
government policies that are put into effect. The Malaysian government's focus on the production of high value palm oil is the critical difference between the policies established in Malaysia and Indonesia. The Malaysian government has also further utilized free trade agreements by investing in the downstream opportunities of the palm oil industry in other FTA membership countries, especially with China. This is one of the most sufficient pieces of evidence for the positive dynamic effect of FTAs.

For further research, it is recommended that the researcher should focus not only on palm oil commodities, but also in the derivatives of palm oil products. Also, the potential use of other techniques on gravity estimation, such as the Heckman Estimation Model, can likely give a more satisfying result.

\section{REFERENCES}

Aksoy, M. A. \& J. Beghin C. (eds). 2004. Global agricultural trade and developing countries (Washington, DC: The World Bank, 2004).

Anderson, J. E. 1979. A Theoretical Foundation for the Gravity Equation. American Economic Review, 69(1), 106-116.

Anderson, J. E., \& E Van Wincoop, 2003. Gravity with gravitas: a solution to the border puzzle. American Economic Review, 93, 170-192.

Bacchetta, M. 2012. A practical guide to trade policy analysis. New York, Geneva: United Nations Conference on Trade and
Development; World Trade Organization.

Balu, N., \& N Ismail. 2011. Free trade agreement -the way forward for the malaysian palm oil industry. Oil Palm Industry Economic Journal, 2, 26-35. Retrieved from http://palmoilis.mpob.gov.my/publ ications /OPIEJ/opiejv11n2balu.pdf

Basiron, Y. 2001. Global oils and fats business: challenges in the new millenium. Oil Palm Industry Economic 1: (1) p. 1-10. Malaysian Palm Oil Board. Malaysia.

Bergstrand, J. A.1985. The gravity equation in international trade: some microeconomic foundations and empirical evidence. The Review of Economics and Statistics, 67(3), 474-481.

Bergstrand, J. A.1989. The generalized gravity equation, monopolistic competition, and the factorproportions theory in international trade. The Review of Economics and Statistics, 71(1), 143-153.

Cheong, D., M. Jansen, \& R Peters. 2013. Shared Harvets: Agriculture, Trade, and Employment. Geneva: International Labour Office.

Ernawati, F., M., Arshad M N., Zainal A.M. Shamsudin, Met. 2006. AFTA and its implication to the export demand of Indonesian palm oil. Jurnal Agro Ekonomi, 24(2), 115-132. Retrieved from http://www.econ. upm.edu.my/ fatimah/AFTA $\% 20$ and $\% 20$ its $\% 20$ implication $\% 20$ to $\% 20$ the $\% 20$ export $\% 20$ demand $\% 2$ 
0of $\% 20$ Indonesioan $\% 20$ Palm $\% 20$ oil.pdf

Fally, T. 2012. Structural gravity and fixed effects. Unpublished Working Paper, University of Colorado-Boulder.

FAO Statistics Division. 2013. Major commodities exporter. [Data File] Retrieved from http://faostat3.fao.org/faostatgateway/go/to/browse /rankings/major commodities_exports/E

Gourieroux, C., A. Monfort, \&, A. Trognon. 1984. Pseudo maximum likelihod methods: application to poisson models. Econometrica, 53(3), 701-720.

Head, K., \& T. Mayer.2013. Gravity equations: Workhorse, toolkit, and cookbook. Centre for Economic Policy Research.

Ibrahim, A.1999. The international trade in palm oil: prospects and challenges. Proceedings from: The 1999 PORIM International Palm Oil Congress. Economics Marketing Conference. Palm Oil Research Institute of Malaysia.

Krugman, P.R. 1980. Scale economies, product differentiation, and the pattern of trade. American Economic Review, 70(5), 950-959.

Krugman, P.R.1991. The move toward free trade zones. Economic Review, 76(6), 5.

Lambert, D. \& S. McKoy. 2009. Trade Creation and Diversion Effects of Preferential Trade Associations on Agricultural and Food Trade. Journal of Agricultural Economics 60 (1):17-39
Lubis, A. (1994). A market model for malaysia palm oil industry. PhD Thesis. Faculty of Economics and Management, University Putra Malaysia, Serdang, Selangor; Malaysia.

Nor, A. M. (2012). Internationalisation of malaysian palm oil-based multinationals. Oil Palm Industry Economic Journal, 12(1), 8-13. Retrieved from http://palmoilis.mpob.gov.myv /publications /OPIEJ/ opiejv12n Anuar.pdf

Philippidis, G., Resano-Ezcaray, H. and Sanjuán-López, A. I. (2013), Capturing zero-trade values in gravity equations of trade: an analysis of protectionism in agrofood sectors. Agricultural Economics, 44: 141-159. doi: 10.1111/agec. 12000

Rifin, A. (2010). Export competitiveness of indonesia's palm oil product. Trends in Agriculture Economics, 3(1), 1-18. Retrieved from http:/www.scialert.net/qredirect.p hp?doi=tae.2010.1.18\&linkid=pdf

Santos Silva, J., \& Tenreyro, S. (2006). The Log of Gravity. Review of Economics and Statistics, 88(4), 641-658. doi:10.1016/j.econlet.2011.05.008

Santos Silva, J., \& Tenreyro, S. (2011). Further simulation evidence on the performance of the Poisson pseudo-maximum likelihood estimator. Economics Letters, 112(2), 220-222. doi:10.1016/j.econlet.2011.05.008 
Shamsuddin, M.N., Fatimah, M.A., Zainalabidin, M. and Lubis, A.R. (1994). A Market Model for Malaysia Palm Oil Industry. The Malaysian Journal of Agricultural Economics 11 (1994): pp 81-102.

Shamsuddin, M.N., A.R, Lubis, and Zainalabidin, 1997. The effect of export duty liberalization on the malaysian palm oil industry. Faculty of Economics and Management, University Putra Malaysia, Serdang.

Shepherd, B. 2013. The Gravity Model of International Trade: A User Guide. United Nations publication. Bangkok.

Sun, L., \&, M. R Reed .2010. Impacts of free trade agreements on agricultural trade creation and trade diversion. American Journal of Agricultural Economics, 92(5), 1351-1363.

doi:10.1093/ajae/aaq076

Suryana, A. 1986. Trade prospects of indonesian palm oil in the international markets for fats and oil. North California State University, United States.

Susila, W.R.1995. Model ekonomi minyak sawit mentah. Pusat Penelitian Sosial Ekonomi Pertanian. Badan Penelitian dan Pengembangan

Tinbergen, J. 1962. Shaping the world economy; suggestions for an international economic policy.
Tondok A.R.1998.Production and marketing of the indonesian palm oil: past present, and the future. International Oil Palm Conference, September 23-25. 1998. BaliIndonesia

United Nations Statistical Division. 2013. Tade Data (UN Comtrade) [Data file]. Retrieved from http://wits.worldbank.org/WITS/ WITS/AdvanceQuery/ RawTradeData/QueryDefinition.as px?Page $=$ RawTradeData

Viner, J.1950. The customs union issue. New York: Carnegie Endowment for International Peace. Retrieved from http://babel.hathitrust.org/ cgi/pt?id=inu.30000005368265;vi ew=1up;seq $=9$

World Bank. 2013. GDP Current (US\$) [Data file]. Retrieved from http://data.worldbank.org/indicator /NY.GDP.MKTP.CD?page $=5$

World Bank. 2013. PPP conversion factor (GDP) to market exchange rate ratio from [Data file]. Retrieved from http://data.worldbank.org/indicator /PA.NUS.PPPC.RF/countries?disp lay $=$ default

WTO.2012. International trade statistics 2012. Lausanne, Switzerland: World Trade Organization.

Yulismi, \& Siregar, H. 2007. Determinant factors of indonesia palm oil export to major importing countries: An error correction model analysis. Economic and Finance in Indonesia 55(1), pp 6588. 
Riska Pujiati, Muhammad Firdaus, Andriyono Kilat Adhi and Bernhard Brümmer 